https://doi.org/10.31426/ijamsr.2018.1.3.139

\title{
ISOLATION, PRODUCTION, CHARACTERIZATION AND PURIFICATION OF ALAKALINE XYLANASE FROM PAPER AND PULP WATSE WATER OF SANGLI KUPWAD MIDC(MH).
}

\author{
Rohit Shankar Mane ${ }^{1}$, Gitanjali Surgonda Patil ${ }^{2}$, Anjani Maruti Patil ${ }^{3}$, \\ ${ }^{1}$ Department of Microbiology and Biotechnology, Karnatak University, Dharwad. Karnataka, India. \\ ${ }^{2}$ Department of Microbiology, K.W.C. Sangli $(M H)$ \\ ${ }^{3}$ Department of Microbiology, P.K.C. Sangli $(M H)$ \\ rohitmane2025@gmail.com
}

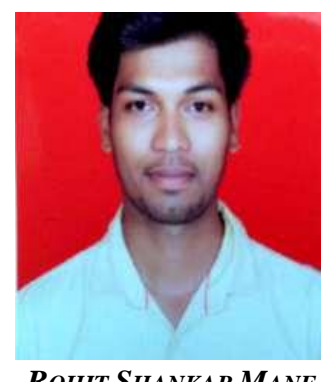

ROHIT SHANKAR MANE

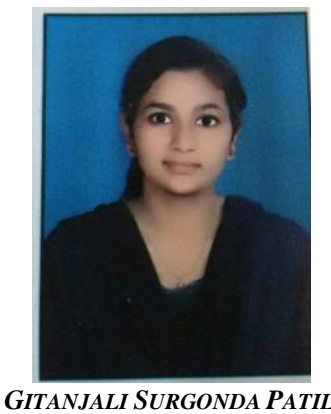

Keywords: Xylane, Xyalanase, Screening, SSF, Partially Purication,

\begin{abstract}
A B S T R A C T
In the present research, 30 xylanase producers were isolated by serial dilution and spread plate method from waste water samples of paper and pulp industry, Kupwad MIDC, Sangli (MH), India. This isolates were named as AG1, AG2 up to AG30. This all 30 isolates were screened for xylanase production by primary and screening. In the primary screening, AG12 showed $1.8 \mathrm{~mm}$ zone of hydrolysis therefore AG12 were selected for Solid State fermentation at $25^{\circ} \mathrm{C}$. AG12 showed highest xylanase production on $5^{\text {th }}$ days of incubation period with $44.12 \mu \mathrm{g} / \mathrm{ml} / \mathrm{Mol}$ activity. Further, xylanase were extracted and purified by Ammonium sulphate precipitation and dialysis with 20 $\mathrm{Mol} / \mathrm{ml} / \mathrm{min}$ and $12.04(\mathrm{U} / \mathrm{ml})$ respectively. The crude Xylanase were characterized by using different parameters such as temperature ranges from $10-50^{\circ} \mathrm{C}\left(\right.$ optima- $\left.30^{\circ} \mathrm{C}\right), \mathrm{pH}$ ranges from 4-10 (optima-pH 8.0).
\end{abstract}

Citation: Rohit Shankar Mane, Gitanjali Surgonda Patil, Anjani Maruti Patil (2018). Isolation, Production, Characterization And Purification Of Alakaline Xylanase From Paper And Pulp Watse Water Of Sangli Kupwad Midc(Mh). International Journal of Advanced Multidisciplinary Scientific Research (IJAMSR ) ISSN:2581-4281

Vol 1, Issue 3, May, 2018, \#Art.139, pp95-100

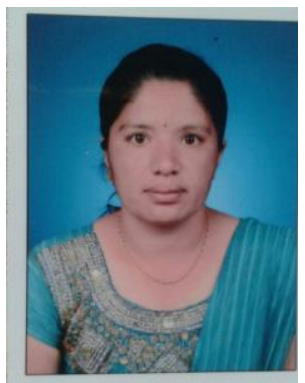

Anjani Maruti Patil 


\section{International Journal of Advanced Multidisciplinary Scientific Research (IJAMSR) ISSN:2581-4281}

\section{Introduction}

Plant cell walls have three major polymeric constituents: cellulose (Insoluble fiberss of 1,4glucan), hemicellulose (non-cellulosic polysaccharides including glucans, mannans and xylans) and lignin (A complex poly phenolic structure). Xylan is the major hemicellulose in wood from angiosperms but is less abundant in the wood from gymnosperms. Structurally Xylan is a homopolymer of Dxylopyranose residues in $\beta(1 \rightarrow 4)$ linkages with a degree of polymerization ranging from 150 to 200 . This backbone is substituted by some of the sugars and organic acids, such as Arabians, glucuronic acid, Ferulic acid, etc. Xylans is broadly classified into four major groups based on its substitutes, which is homoxylan, Arabinoxylans, glucuronoxylan, and glucuronoarabinoxylan. Homoxylans contain xylose residues only, and can be either linear or branched. Arabinoxylans consist of a $(1 \rightarrow 4)-\beta$-Xylan main chain, but is substituted with $\alpha$-arabinosyl residues. The $\beta$ $(1 \rightarrow 4)$-linked D-xylopyranosyl residues are substituted with one $\alpha-(1 \rightarrow 2)$-linked 4- $O$-methyl-D-glucuronic acid in the case of glucuronoxylan; while in glucuronoarabinoxylan, the same backbone is linked to arabinofuranose and uronic acid (Gröndahl et al. 2003; Bergmans et al. 1996).

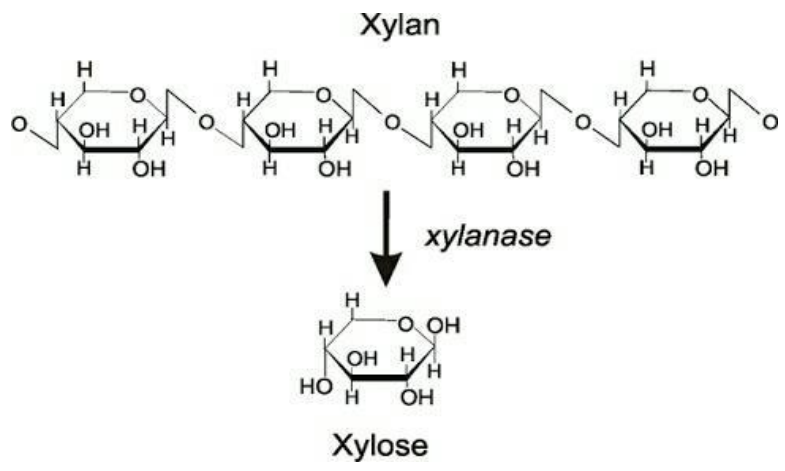

Figure 1. Structure and action of Xylanase

The side chains determine the solubility, physical conformation, and reactivity of Xylan molecules with other home cellulosic components, and, hence, greatly influence the mode and extent of enzymatic cleavage. In terrestrial plants Xylan is composed of a backbone of glycosidically $1,4-$ linked xylopyranose but in marine algae -1,3-linked back bone are found (Dekker \& Richards 1976). Softwood contains $10-15 \%$ Xylan as arabino-4-0 methyl glucuronoxylan. This material, which is not acetylated, contains D-xylopyranose, 4-0methyl D

Glucuronic acid and L-arabinose in a ratio of 1000:20:13. 000:20:13. The O-acetyl groups present at $\mathrm{C} 2$ and $\mathrm{C} 3$ positions of xylosyl residues inhibit xylanase from completely degrading acetyl Xylan probably by stearic hindrance. So the synergistic action of acetyl Xylan esters and Xylanase is necessary for the complete hydrolysis of acetyl Xylan.

Xylanase is the name given to a class of enzymes which degrade the linear polysaccharide $\beta-1,4-X y l a n$ into xylose, thus breaking down hemicellulose, one of the major components of plant cell walls. Xylanase are produced extracellularly by bacteria, yeast and filamentous fungi. The fungal genera Trichoderma, Aspergillus, Fusarium, and Pichiaare considered great producers of xylanases. Microbial xylanases have important applications in the degradation of Xylan. Substrate xylan, a biopolymer comprising of Dxylose monomers linked through $\beta 14$ glycosyl bond, is found abundantly in lignocellulosic biomass. It can be classified as endo and exoxylanases (Min.Jen et al., 2002). Exoxylanases ( $B$ D-xylopyranosidase) is sometimes referred to as extracellular xylanase. Xylanases have been classified in at least three ways: based on the molecular weight and isoelectric point (pI) , the crystal structure and kinetic properties, or the substrate specificity and product profile. A wide variety of Microorganisms live in nature at various temperatures for their survival. They not only survive at high temperature but also carried out their activities according to maintained conditions. Many enzymes such as chitinases, amylase, protease, lipases, Xylanases etc. are industrially important.

Xylanolytic enzymes are inducible. It is produced in high amount during the growth on Xylan, the synthesis of enzyme are easily metabolized carbon source such as glucose or xylose. Therefore Xylan cannot enter into the cell, the oligosaccharide produced, but the hydrolysis of Xylan in the medium by small amount of xylanases produces continuously. Induction of various synthetic alkyl and aryl one $\beta$-D xylosides.

Xylanases can be produced using two main methods.

1. Solid state fermentation 2. Submerged fermentation 


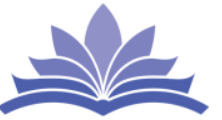

I J A M S R

\section{International Journal of} Advanced Multidisciplinary Scientific Research (IJAMSR) ISSN:2581-4281

Most of the researchers used submerged cultures, which allows control over the degree of aeration, $\mathrm{pH}$ and temperature of the medium, and control over other environmental factors required for optimum growth of microorganisms.

Interest in hemicellulytic enzyme has increased remarkably during recent years. This is mainly due to new areas of application of these enzymes within the pulp and paper industry. Among those the most promising seems to be utilization of hemicellulose, especially xylanases to increase the bleachability to craft pulps. This is partly due to the greatest potential of an environmental safe method. The main enzymes needed in aided which have been belong to group of endo, beta xylanases. Xylanases act mainly on the located.

Recipted xylan on the surface of pulp fibrus. enzymetic hydrolysis of this specific type of xylans renders the structure of fibres more permeable allowing. Enhanced extraction of residual lignin from fibres.

The hydrolysis of hemicellulses in the inner fiber layers.may also enhance the bleachability. The main goals in enzymes added bleaching of kraft pulps have been a reduction of congestion of chlorine chemicals in bleaching process and consequent lowering of the action of the effluents.

In the production of totally chlorine free pulp, enzymes have been successfully used for increases the brightness of pulp of the other suggested enzymatic modification of fibres are in at improved drainage in the paper machine, improvement of fibres properties of production of dissolving pulps.

The present research study was carried out in the investigation of novel xylanases from bacteria under standard and maintained conditions by offering following materials and methods.

\section{Methods and Materials:}

\subsection{Sample collection}

The waste water sample of paper and pulp industry of Kupwad MIDC, Sangli (MH), India was collected in bottles and brought to the laboratory for further procedure.

\subsection{Isolation of micro organism}

The collected samples were serially diluted and the highest dilution $\left(10^{-7}\right)$ was spread on a sterile nutrient agar plate and incubated at $37^{\circ} \mathrm{C}$ for $24 \mathrm{hrs}$. The plates were observed in isolated colonies of microorganisms.

\subsection{Primary screening of xylanase producers}

Isolated microorganisms were spot inoculated on sterile Mendel and Reese agar medium containing $1 \%$ xylan and these plates were incubated for 48 hours at $37{ }^{\circ} \mathrm{C}$. After 48 hours of incubation period, the plates were flooded with a $1 \%$ Congo red solution.

\subsection{Xylanase Production}

Solid-state fermentation was employed for production of xylanase. $50 \mathrm{~g}$ of Rice bran and $20 \mathrm{ml}$ distilled water were transferred to the seven individual $500 \mathrm{ml}$ cotton plugged Erlenmeyer flasks. The flasks were autoclaved at $15 \mathrm{lb} /$ inch 2 pressure and $121^{\circ} \mathrm{C}$ for $15 \mathrm{~min}$., and cooled the medium at room temperature. The xylanase positive microorganisms were inoculated in SSF and incubated for 7 days for xylanase production.

\subsection{Xylanase Extraction}

After 14 days of incubation period, $30 \mathrm{ml}$ of $0.05 \mathrm{M}$ Phosphate buffer ( $\mathrm{pH}$ 6.0) was added to the fermented substrate in first flask. The contents of the flask were crushed with the help of a glass rod and flasks were rotated on a rotary shaker at $120 \mathrm{rpm}$ for $1 \mathrm{~h}$ at $30^{\circ} \mathrm{C}$ afterwards the fermented medium filtered through whatman filter no. 1 filter paper. After filtration, the contents were centrifuged at 5,000 RPM for $10 \mathrm{~min}$ at $4^{\circ} \mathrm{C}$ and clear supernatant from each of the tubes was collected for further studies and tubes was stored at $4{ }^{\circ} \mathrm{C}$ until used. This whole procedure was repeated for remaining six SSF flasks.

\subsection{Xylanase Activity}

Xylanase activity was assayed by using DNS method to measure the amount of reducing sugar liberated from Xylan. The crude enzyme protein was used for measuring the activity at $\mathrm{pH} 6$ (phosphate buffer, 0.5) at $37^{0} \mathrm{c}$ for $30 \mathrm{~min}$.

\subsection{Xylanase unit activity}

According to the International Union of Biochemistry 1 enzyme International unit has been defined as amount of enzyme required to release $1 \mu \mathrm{mol}$ of reducing sugar in 1 $\min$. at $40^{\circ} \mathrm{c}$ and at atmospheric pressure. 


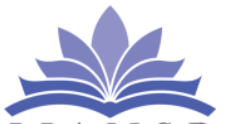

I J A M S R

\section{International Journal of Advanced Multidisciplinary Scientific Research (IJAMSR) ISSN:2581-4281}

\subsection{Characterization of crude Xylanase}

The obtained crude xylanase enzyme was used for further characterization.

\subsubsection{Effect of temperature on Xylanase activity}

The effect was carried out by adjusting reaction mixture at different temperature ranges from $4{ }^{\circ} \mathrm{C}$ to 60 ${ }^{\circ} \mathrm{C}$.

The reaction mixture was incubated at different adjusted temperature, such as $4^{\circ} \mathrm{C}, 32^{\circ} \mathrm{C}, 50^{\circ} \mathrm{C}, 60^{\circ} \mathrm{C}$, .For 15 minutes and xylanase activity was measured using above mentioned protocol at absorbance 540nm.

\section{8.2 Effect of pH on xylanase activity}

The effect of $\mathrm{PH}$ was carried out by adjusting the reaction mixture at different $\mathrm{pH}$ ranges on xylanase activity of crude xylanase enzyme from $5,6,7,8,9,10$.using $\mathrm{pH}$ of phosphate buffer $[0.1 \mathrm{M}]$ were used during the study of the effect of $\mathrm{pH}$.

\subsubsection{Partial purification of xylanase enzyme}

The fermented broth by solid state fermentation in which the broth is taken out. The fermented broth was centrifuged to remove cell debris. The supernatant was taken for ammonium sulphate precipitation. The proteins are commonly present in supernatant which neutralized by addition of salt. The amount of salt used for precipitation depends on volume of supernatant taken as well as a percentage of the salt precipitation.

The $80 \%$ salt precipitation was done and ammonium sulfate salt was added pinch wise in the crude enzyme at $4^{\circ} \mathrm{C}$ on a magnetic stirrer.

\section{Dialysis of crude enzyme}

The semipermeable membrane like dialysis bag was used for removing ammonium salt from the crude enzyme by desalting.

\section{Protein Determination}

The protein concentration was estimated according to the method of Lowry et al using Bovine serum albumin as the standard.

\section{Results:}

\section{Isolation, Production of Xylanase}

30 isolates were obtained from the paper and pulp industry of Kupwad MIDC, Sangli (MH), India. They

were labelled as AG1, AG2 up to AG30 and sub cultured on sterile nutrient agar slants in the duplicates and preserved at $4{ }^{\circ} \mathrm{C}$. The results were shown in table I. In the primary screening of Xylanase production AG12 showed highest zone of hydrolysis at $1.8 \mathrm{~cm}$ after flooding with $1 \%$ Congo red. This same AG12 were selected for solid state fermentation on rice bran with Xylan as a substrate for 7 days. The results were shoed in table II. AG12 showed highest xylanase production on $6^{\text {th }}$ days of incubation period under static conditions, therefore xylanase were partially purified by using a solvent extraction method, ammonium sulfate precipitation and dialysis respectively.

Table I: Colony size and zone of hydrolysis showed by isolates.

\begin{tabular}{|c|c|c|c|}
\hline Sr. No. & Isolate No. & $\begin{array}{l}\text { Colony size } \\
(\mathrm{mm})\end{array}$ & $\begin{array}{l}\text { Hydrolysis } \\
\text { Zone (mm) }\end{array}$ \\
\hline 1 & AG1 & 0.3 & 0.4 \\
\hline 2 & AG2 & 0.2 & 0.6 \\
\hline 3 & AG3 & 0.3 & 0.8 \\
\hline 4 & AG4 & 0.4 & - \\
\hline 5 & AG5 & 0.2 & 0.6 \\
\hline 6 & AG6 & 0.3 & 0.4 \\
\hline 7 & AG7 & 0.1 & - \\
\hline 8 & AG8 & 0.1 & 0.9 \\
\hline 9 & AG9 & 0.3 & 0.7 \\
\hline 10 & AG10 & 0.5 & 1.2 \\
\hline 11 & AG11 & 0.4 & 15 \\
\hline 12 & AG12 & 0.3 & 1.8 \\
\hline 13 & AG13 & 0.3 & - \\
\hline 14 & AG14 & 0.2 & 1.4 \\
\hline 15 & AG15 & 0.4 & - \\
\hline 16 & AG16 & 0.2 & 1.5 \\
\hline 17 & AG17 & 0.1 & 1.2 \\
\hline 18 & AG18 & 0.4 & - \\
\hline 19 & AG19 & 0.5 & 0.4 \\
\hline 20 & AG20 & 0.2 & 0.9 \\
\hline 21 & AG21 & 0.1 & 0.8 \\
\hline 22 & AG22 & 0.2 & 0.6 \\
\hline 23 & AG23 & 0.4 & 0.4 \\
\hline 24 & AG24 & 0.3 & 1.2 \\
\hline 25 & AG25 & 0.3 & 1.3 \\
\hline 26 & AG26 & 0.3 & 1.2 \\
\hline 27 & AG27 & 0.2 & 0.6 \\
\hline 28 & AG28 & 0.3 & 0.4 \\
\hline 29 & AG29 & 0.3 & 0.4 \\
\hline 30 & AG30 & 0.1 & - \\
\hline
\end{tabular}

Table II. Selection of AG12

\begin{tabular}{|l|l|l|l|}
\hline $\begin{array}{l}\text { Isolate } \\
\text { No }\end{array}$ & $\begin{array}{l}\text { Colony Size } \\
(\mathrm{mm})\end{array}$ & $\begin{array}{l}\text { Hydrolysis } \\
\text { zone }(\mathrm{mm})\end{array}$ & $\begin{array}{l}\text { Xylanase activity } \\
\mu \mathrm{g} / \mathrm{ml} / \mathrm{Mol}\end{array}$ \\
\hline AG12 & 0.3 & 1.8 & 6.08 \\
\hline
\end{tabular}


https://doi.org/10.31426/ijamsr.2018.1.3.139

\section{International Journal of I J A M S R Advanced Multidisciplinary Scientific Research (IJAMSR) ISSN:2581-4281}

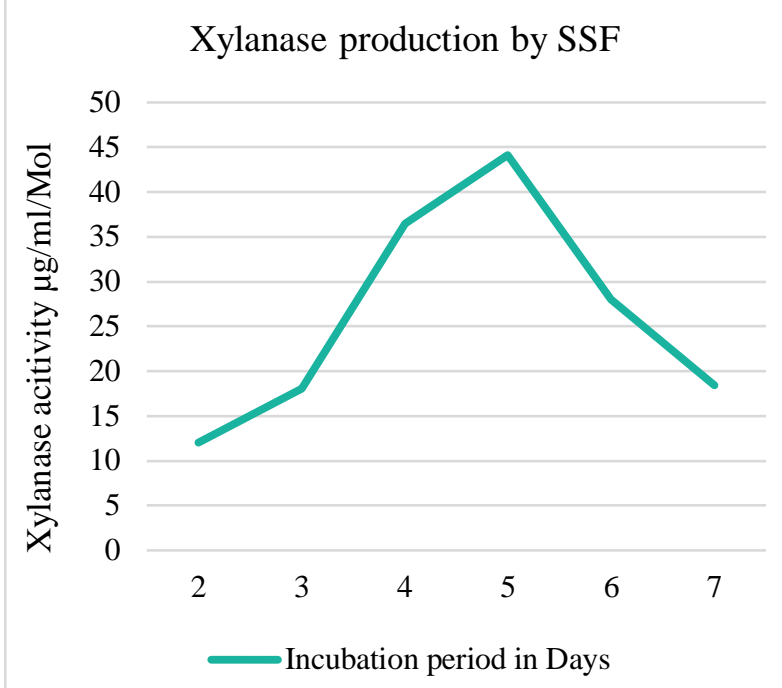

Figure 2: Xylanase production by SSF

\section{Purification and characterization of xylanase}

In brief, extracted crude xylanase were precipitated by ammonium sulfate salt by $80 \%$ and further protein concentration were determined by its specificity. Enzyme activity was observed as well as protein estimation was done by using the Folin Lowry method.

Table 3; Activity of precipitated Xylanase

\begin{tabular}{|l|l|l|l|}
\hline Sample & $\begin{array}{l}\text { Enzyme } \\
\text { activity } \\
(\mathbf{U} / \mathbf{m l})\end{array}$ & $\begin{array}{l}\text { Protein } \\
\text { Concentration } \\
\mu \mathrm{m} / \mathrm{ml} / \mathrm{min} .\end{array}$ & $\begin{array}{l}\text { Enzyme } \\
\text { specificity } \\
\mathrm{Mol} / \mathrm{ml} / \mathrm{min}\end{array}$ \\
\hline $80 \%$ & 16.05 & 700 & 20 \\
\hline
\end{tabular}

This same precipitated xylanase were submerged in dialysis for partially purification and the results were shown in table 4.

Table 4: Activity of partially purified Xylanase

\begin{tabular}{|l|l|}
\hline Sample & Enzyme activity (U/ml) \\
\hline $\begin{array}{l}\text { Partially } \\
\text { enzyme }\end{array}$ & 12.04 \\
\hline
\end{tabular}

Such partially purified xylanase were further characterized at different temperature and $\mathrm{pH}$.

According to xylanase activity and graph it seems that, Xylanase was active at temperature $25^{\circ} \mathrm{C}$ and $\mathrm{pH} 8$.

\section{Effect of temperature on xylanase production}

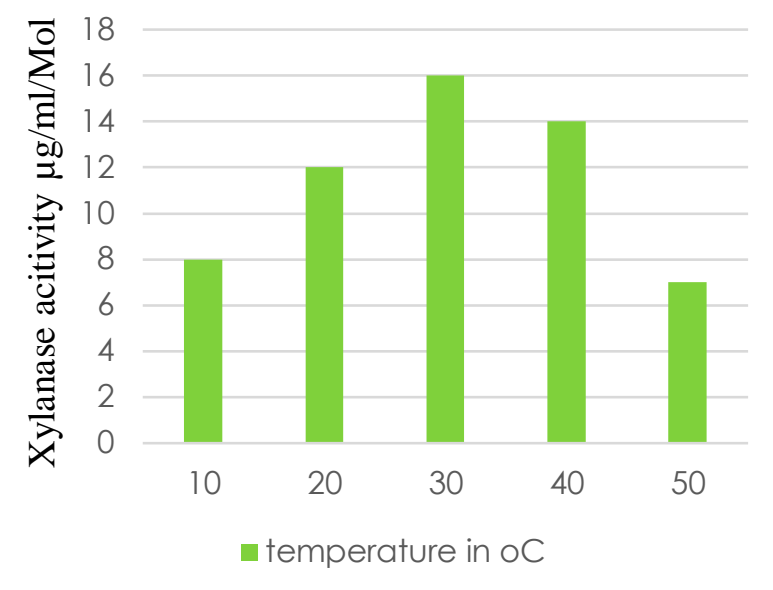

Figure 4; Effect of temperature on Xylanase production

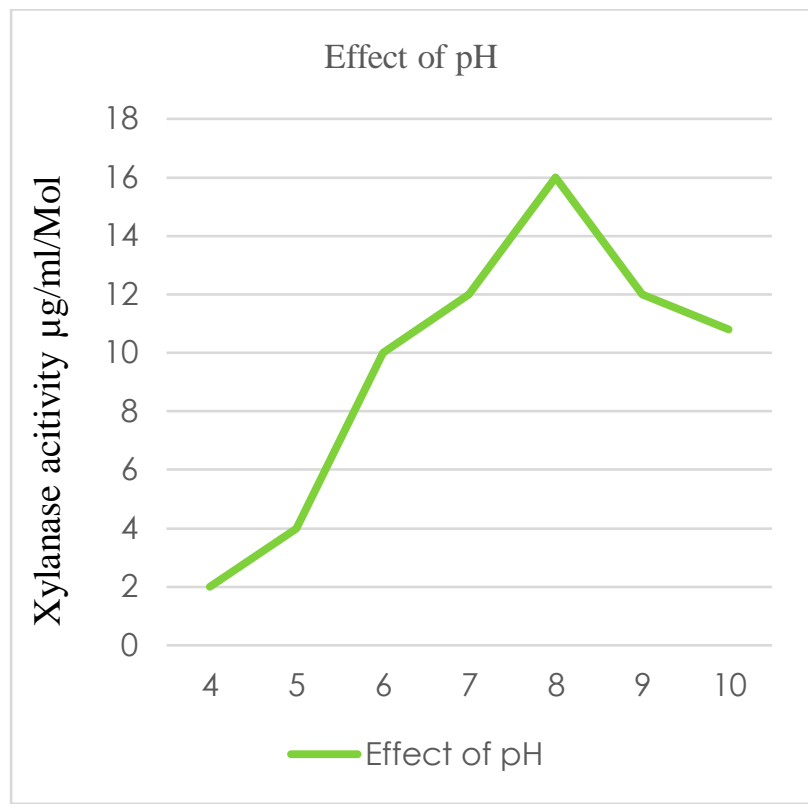

Figure 4: Effect of $\mathrm{pH}$ on xylanase production

\section{Discussion:}

Xylanase production, microbial study is rare in literature from pulp and paper industrial waste water.

F. A. Alebious worked on the production of xylanase from fungal isolates by solid state fermentation using sugar cane baggase. As agricultural residue studied on 
the optimum condition of temperature and $\mathrm{pH}$ a range from $30^{\circ} \mathrm{C}-80^{\circ} \mathrm{C}$ and $\mathrm{pH}-3$ to 9 . Comparative studies of the enzyme for its activity as produced by XM, XD and $\mathrm{XC}$ were $3000 \mathrm{U} / \mathrm{ml}, 2800 \mathrm{U} / \mathrm{ml}$ and $3400 \mathrm{U} / \mathrm{ml}$ respectively.

Scientist N. Balamani et al., (2008) also worked on xylanase production from Pseudomonas putida and Staphylococcus aureus. wheat bran supported maximum xylanase production in both species. The culture medium with pH-6.5 and tempetrature- $40^{\circ} \mathrm{C}$ in Pseudomonas putida and $\mathrm{pH}-6$ and temperature $-45^{\circ} \mathrm{C}$ in Staphylococcus aureus promoted the growth and maximum xylanase production.

Hiremath. K.S et al., (2011) worked on-isolation, production and characterization of alkaline thermostable xylanase from newly isolated Bacillus spp. -application on the paper and sugar industrial waste are used to screen and produce the xylanase. The industrial waste of paper industry shows the maximum synthesis of xylanase at $\mathrm{pH}-9-12$ and temperature $35-70^{\circ} \mathrm{C}$ for $18-24$ hrs. The produced alkaline thermostable xylanase by Bacillus Species show the most Xylanolytic activity at $\mathrm{pH}>10$ at $70^{\circ} \mathrm{C}$.

Karunakaran et al., (2014) worked on-xylanase production from Aspergillus Niger. -by submerging fermentation studied on agricultural soil, decayed bread and waste material. The maximum concentration of xylanase at $25^{\circ} \mathrm{C}$ and $\mathrm{pH}$ of 6 .

In our project we used $1 \%$ Xylan as a substrate and the enzyme activity $12.04 \mathrm{U} / \mathrm{ml}$ at $\mathrm{pH} 7$ and temperature $50^{\circ} \mathrm{C}$.

\section{Conclusion:}

The production of xylanases widely applied in the field of chemistry, biomedical, biotechnological, agricultural and environmental protection. Wide scope for extensive research to achieve industrial scale production from the xylanase by Solid State Fermentation.

Therefore present xylanase is novel in nature.

\section{References}

1. Ajay Singh, Ramesh, Chander Kuhad, and Manish Kumar. Enzyme Microb.Technol.1995, 2 (6). 26-31.

2. Xylanase production by a hyper xylanolytic mutant of fusarium oxysporum jou. Mic. bio 1995. 2(4). 456459.

3. Annie Deborah Harris and C .ramalingum. Journal of Experimental Sciences.2010. 1(7), 01-1.

4. Bushra kalim, Nils Bohringer, Nazish Ali ${ }^{1}$ and Till $F$. Schaberle, .British Biotechnology Journal. 2015. 7(1), 1-20.

5. F.A.Alebiouus,A.K.Lawal,S.O.Olatope,Y.L.Subaru,K. A.Shittu,F.A.Orji,O.D.Adelaja,A.I.Ugbana, O.A,Esan, E.N.Dike and G.N.Elemo. Inernational Journal of Current Microbiology and Applied Sciences. 2015. 4(12).323-331.

6. Girish $k$ Goswami and seema rawat IInternational Journal of Current Research and Academic Review. 2015 3(6) 436-450.

7. Hiremath. K.S and Patil. C.S International Journal Biotechnology Applications. 2011. 3(1), 48-51.

8. Manju Phadke and Zahera Momin. IOSR Journal of Biotechnology and Biochemistry. 2015. 1(2) 38-45.

9. M.P. Prasad and Rekha sethi .International Journal of Current Microbiology and Applied Science. 2013. 2(12). 489-492.

10. N. Balamani, V. SASHI,N.S. MALATHY and S. GNANASOUNDARI. International Journal of Plant Sciences. 2008. 3(2). 401-403. 